\title{
The association between ADHD and eating disorders/pathology in adolescents: A systematic review
}

\author{
Carol Curtin $^{1}$, Sherry L. Pagoto ${ }^{2}$, Eric Mick ${ }^{3}$ \\ ${ }^{1}$ Family Medicine \& Community Health, E.K. Shriver Center, University of Massachusetts Medical School, Waltham, USA \\ ${ }^{2}$ Division of Behavioral and Preventive Medicine, University of Massachusetts Medical School, Worcester, USA \\ ${ }^{3}$ Quantitative Health Sciences, University of Massachusetts Medical School, Worcester, USA \\ Email: carol.curtin@umassmed.edu
}

Received 3 September 2013; revised 3 October 2013; accepted 10 October 2013

Copyright (C) 2013 Carol Curtin et al. This is an open access article distributed under the Creative Commons Attribution License, which permits unrestricted use, distribution, and reproduction in any medium, provided the original work is properly cited.

\section{ABSTRACT}

Background: Attention-Deficit/Hyperactivity Disorder (ADHD), one of the most common neurodevelopmental conditions of childhood, is associated with high rates of mood and behavioral disorders. Preliminary evidence suggests that ADHD may also be associated with eating disorders (ED) or eating pathology (EP). This systematic review synthesizes the extant published literature on this association among youth ages 12 - 21 years. Methods: Literature searches were performed using Medline, Ovid/Psych Info, Google Scholar, and via manual inspection of bibliographies. Crosssectional, case-control, and prospective studies published in English with sample sizes larger than 50, participant ages 12 - 21 years, and assessed ADHD and ED or EP, were considered for review. Case reports, feeding, and drug studies were excluded. Results: Preliminary searches yielded 337 articles; eight articles met inclusion/exclusion criteria. Two studies documented an association between ADHD and ED, and three studies found an association between ADHD and EP. Youth with ADHD were nearly 3 to 6 times more likely to develop an ED than youth without ADHD, and were also more likely to have higher rates of EP, body dissatisfaction, and desire to lose weight/ drive for thinness. Impulsivity was predictive of EP, and ADHD youth with co-occurring mood/behavioral disorders and punitive parental relationships were at higher risk. Conclusions: Five of eight studies documented an association between ADHD and ED or EP in adolescents. Future research is needed to confirm and refine further these findings. The findings have clinical implications, including the inclusion of ED/EP in screening and anticipatory guidance efforts. Evaluating whether medical management of ADHD may be efficacious in preventing and/or treating ED/EP is also warranted.

Keywords: ADHD; Adolescents; Eating Disorders; Eating Pathology

\section{INTRODUCTION}

Attention Deficit Hyperactivity Disorder (ADHD) is one of the most common neurodevelopmental disorders of childhood; estimates indicate that approximately 3\% $5 \%$ of youth have ADHD [1,2]. Core features include developmentally inappropriate levels of inattention, impulsivity, distractibility and motoric over-activity. A wealth of research exists on the cognitive, learning, and behavioral challenges that children and adults with ADHD experience, and there is growing interest in whether the core features of ADHD contribute to maladaptive healthrelated behaviors, including eating disorders (ED).

Eating disorders are composed of several separate but overlapping syndromes characterized by abnormal eating behaviors and preoccupations along with high levels of body dissatisfaction. The DSM-IV [2] characterizes Anorexia Nervosa (AN) by the refusal to maintain a minimally normal body weight. Bulimia Nervosa (BN) is characterized by repeated episodes of binge eating followed by compensatory behaviors such as vomiting, misuse of laxatives or diuretics, or excessive exercise. A disturbance in perception of body shape and weight are core features of both AN and BN. In this review, the term "eating disorder" (ED) refers to syndromes that meet DSM-IV diagnostic criteria for eating disorders, whereas the terms "eating pathology" (EP) or "eating disorder symptoms" refer to individual eating behaviors or symptoms that are indicative of problematic or aberrant eating but do not meet full diagnostic criteria for ED.

The lifetime prevalence of ED in adolescents was es- 
timated by Swanson et al. [3] using data from the National Comorbidity Survey Replication Adolescent Supplement (NCS-A), a nationally representative sample of US adolescents aged 13 to 18 years. The authors found that the prevalence of $\mathrm{AN}, \mathrm{BN}$, and binge eating disorder (BED) are $0.3 \%, 0.9 \%$, and $1.6 \%$, respectively. No sex differences were found in the prevalence of $A N$ or subthreshold BED; however, the prevalence of BN, BED, and sub-threshold AN was higher in girls. The median age for the onset of EDs was between 12 and 13 years of age. ED is associated with significant adverse consequences, including death, suicide, and other medical and psychiatric comorbidities $[3,4]$. Early detection and treatment are linked to better outcomes.

Several potential reasons for an association between ED and ADHD are plausible. One possibility is that ED is but one of many co-occurring behavioral health disorders commonly associated with ADHD. The psychiatric sequelae of ADHD are well-established; children and adolescents with ADHD are at high risk for depressive, anxiety, mood, conduct, and substance abuse disorders [5-8]. It is possible that ED is associated with these comorbidities and not directly related to ADHD per se. However, it is also possible that the core symptoms of ADHD give rise to pathological eating patterns. Barkeley [9] has described ADHD as a disorder of behavioral inhibition, a component of which is the ability to self-regulate. A dimension of self-regulation is the capacity to inhibit one's impulses, a deficit commonly seen in ADHD. Impulsivity has been shown to be a characteristic of patients with BED and $\mathrm{BN},[10-14]$ often observed as emotional reactivity or the tendency be emotionally triggered by undesirable events or negative affect.

As yet, no work has been done to summarize the literature on ED in adolescents with ADHD, despite the fact that the onset of ED most often occurs during this phase of life. Documenting such an association has important implications for early identification and treatment of this potential comorbidity. Accordingly, the purpose of this systematic review is to synthesize the published literature on the association between ADHD and ED among youth ages $12-21$ years.

\section{METHODS}

Searches to identify relevant articles were performed in Medline, Ovid/Psych Info, and Google Scholar and via manual inspection of bibliographies of selected articles. Keywords and MeSH terms used in these searches included: Attention-Deficit/Hyperactivity Disorder; ADHD; anorexia; bulimia; binge eating disorder; eating; eating disorders; and eating pathology.

The search yielded articles published between 1971 and 2012, which were then considered for review. Inclu- sion criteria included: studies with sample sizes larger than 50; participant age 12-21 years; cross-sectional, prospective or case-control studies; and examination of both ADHD and eating pathology. Case studies, laboratory feeding or drug studies, reviews, and opinion articles were excluded, as were articles not published in English. The following data were abstracted from articles meeting inclusion criteria: age range; sample size; sex distribution; study design; source population (e.g., psychiatrically referred or population-based data); methods of assessing $\mathrm{ADHD}$ and $\mathrm{ED} / \mathrm{EP}$; findings on the association between $\mathrm{ADHD}$ and ED/EP; and covariate analyses.

Quality reviews were conducted using modified Downs \& Black criteria [15]. The Downs \& Black quality assessment rubric was originally developed to evaluate both randomized and non-randomized studies and contained 27 criteria. For the present review, the criteria were modified by removing items that were applicable only to randomized trials, yielding a final rating scale of 0 - 18. A higher score is indicative of higher quality. Although the Downs \& Black checklist does not specify a cut-off score to indicate acceptable studies, the mid-point score of 9 was used to distinguish between those studies of adequate vs. inadequate quality [16]. One investigator (CC) performed the abstractions and quality ratings. Decisions about inclusion and exclusion criteria were made by two investigators (CC and EM). The findings of the eight included studies reviewed and confirmed by all three investigators (CC, EM, SP), who also contributed to the discussion.

\section{RESULTS}

After excluding duplications, the preliminary search yielded 337 articles; 276 of these were excluded based on the title or abstract review when it became apparent that the article was not germane to the topic. Sixty-two articles were selected for full article review. Of these, seven articles met full criteria for inclusion and one article was identified from the reference lists of the included articles. Thus, eight articles are summarized in the present review [17-24]. Figure 1 depicts the article selection and review process.

The results of the eight studies included in the review are summarized in Table 1, including sample composition and size, assessment methods for predictors and outcomes, summary of key findings, and quality rating. Two studies $[22,24]$ were performed on large populationbased datasets and a third study was based on a large community sample of adolescents [21]. Four studies were comprised of large samples of youth with ADHD ascertained within clinical settings or specialized camps designed for research in children with ADHD [17-20]. One study was comprised of inpatients hospitalized for eating disorders [23]. Biederman, [17] Yoshimasu, [24] and Mi- 


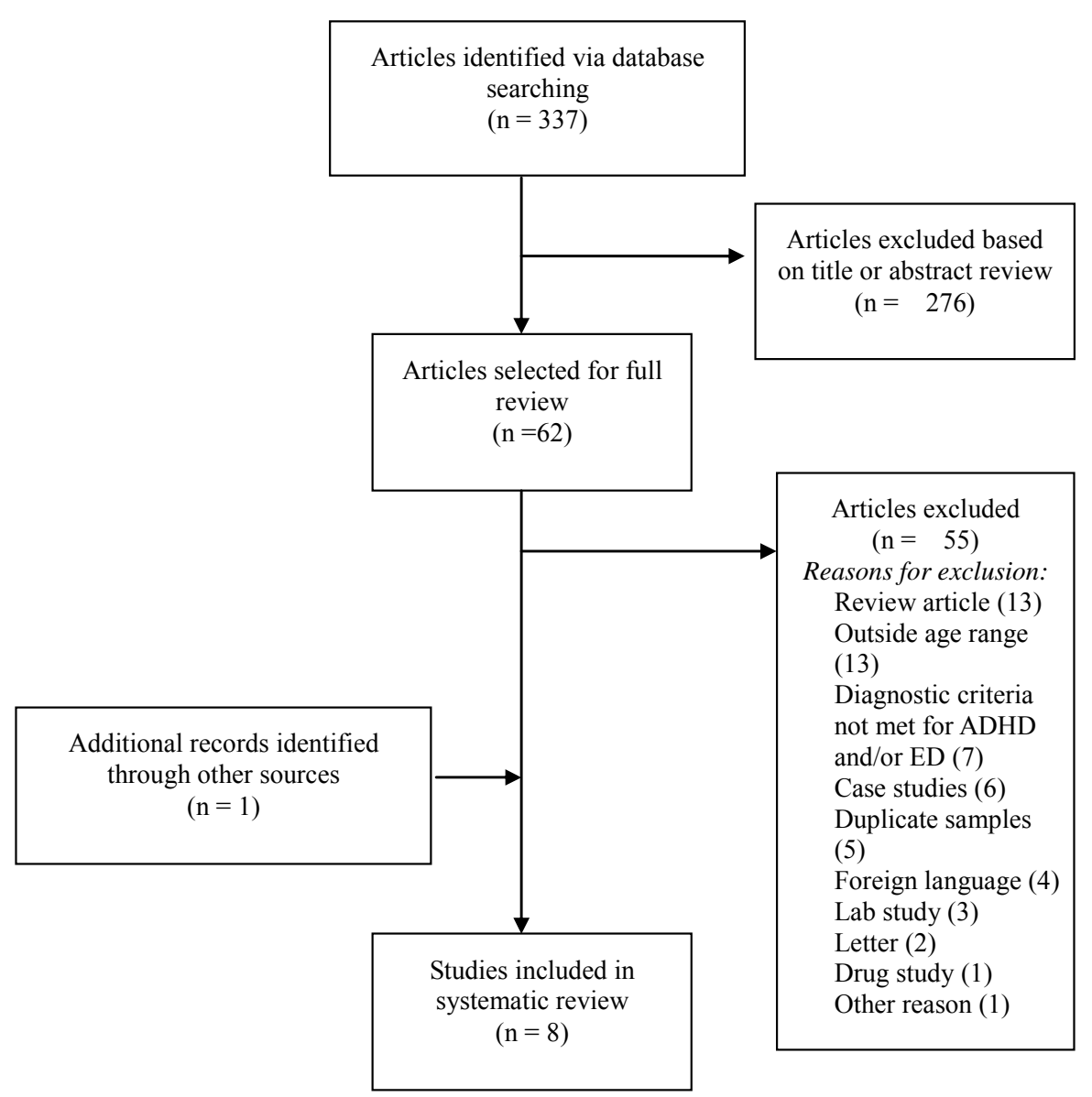

Figure 1. Article identification and abstraction process.

kami [20] and their colleagues conducted retrospective cohort studies while the remainder examined associations within cross-sectional or case-control studies. Half of the studies included only female samples $(\mathrm{n}=4)[17,20,21$, 23 ] while the other half included both males and females $(\mathrm{n}=4)[18,19,22,24]$. The quality rating scores using modified Downs \& Black criteria [15] ranged from 12 to 18; all were above the midpoint, indicative of acceptable quality, and there were no outliers.

\subsection{ADHD and Diagnosed Eating Disorders (ED)}

Six studies attempted to evaluate the association between ADHD and ED that met diagnostic criteria for full or partial syndromes. Only two studies found such an association (Table 1). Biederman et al. [17] compared girls with and without ADHD in a prospective cohort followed for 5 years and found that $16 \%(n=20)$ of the ADHD sample had an eating disorder compared to 5\% (n $=5$ ) of the control group. Over the follow-up period, girls with ADHD were over three times more likely (HR $=3.6,95 \% \mathrm{CI}=1.4-9.9, \mathrm{p}<0.01)$ to develop an eating disorder than girls without ADHD. In addition, rates of
$\mathrm{BN}$ were elevated for this group $(\mathrm{HR}=5.6,95 \% \mathrm{CI}=$ $1.6-19.0, \mathrm{p}<0.01$ ); however, rates of $\mathrm{AN}$ were not found to be statistically significant $(\mathrm{HR}=2.795 \% \mathrm{CI}=$ $0.89-8.7, \mathrm{p}=0.09$ ). The authors conducted a stratified analysis among girls with ADHD, finding that those with confirmed eating pathologies were more likely to have major depressive, multiple anxiety, or conduct disorders than their ADHD counterparts who did not have evidence of ED.

Yoshimasu and colleagues [24] analyzed data from a prospective cohort of youth from population-based hospital and medical records in Rochester, MN. They found that six $(n=6,1.9 \%)$ of 343 youth with ADHD in the sample had an ED compared to two $(n=2,0.3 \%)$ of 712 non-ADHD youth. After adjusting for sex and mother's age and education at birth, youth with ADHD were nearly six times more likely to develop an ED than those without ADHD (HR $=5.68,95 \% \mathrm{CI}=1.14-28.21, \mathrm{p}=$ $0.03)$. Although the hazard ratios for ED among youth with ADHD were elevated, the small sample size of ADHD youth classified with ED and the lack of detailed information on how ED was ascertained render findings that should be interpreted with caution. 
Table 1. Table of evidence - the association between ADHD and eating disorders (ED) and eating pathology (EP) in adolescents.

\begin{tabular}{|c|c|c|c|c|c|c|c|c|}
\hline $\begin{array}{l}\text { Author } \\
\text { year }\end{array}$ & $\begin{array}{l}\text { Type of } \\
\text { study }\end{array}$ & $\begin{array}{c}\text { Source } \\
\text { population }\end{array}$ & Sample size & $\begin{array}{l}\text { Outcomes/ } \\
\text { assessment } \\
\operatorname{method}(\mathbf{s})^{\mathrm{a}}\end{array}$ & $\begin{array}{l}\text { Results for } \\
\text { eating disorders } \\
\text { (ED) }^{\text {b }}\end{array}$ & $\begin{array}{l}\text { Results for } \\
\text { eating } \\
\text { pathology } \\
\text { (EP) }\end{array}$ & $\begin{array}{l}\text { Covariate } \\
\text { adjustment for } \\
\text { confounding }\end{array}$ & $\begin{array}{c}\text { Quality } \\
\text { rating } \\
\text { Range: } \\
0-18\end{array}$ \\
\hline $\begin{array}{l}\text { Biederman } \\
\text { et al. } 2007\end{array}$ & $\begin{array}{c}\text { Prospective } \\
\text { cohort }\end{array}$ & $\begin{array}{c}\text { Psychiatrically } \\
\text { referred } \\
\text { (ADHD) } \\
\text { HMO } \\
\text { participants } \\
\text { (controls) } \\
\text { Ages } 10-25 \text { y. } \\
100 \% \text { female }\end{array}$ & $\begin{array}{l}\bullet \text { Total } \mathrm{N}=235 \\
\circ \text { ADHD } \\
\mathrm{N}=123 \\
\circ \text { Controls } \mathrm{N}= \\
112\end{array}$ & $\begin{array}{l}\text { Outcomes: } \\
\text { - AN } \\
\text { - BN } \\
\text { - ED-C } \\
\text { - diagnoses } \\
\text { included (half or more } \\
\text { of DSM criteria) } \\
\text { Assessment: } \\
\text { - KSADS-E for pts < } \\
18 \text { yrs. } \\
\text { - DISC for } \\
\text { participants > } 18 \text { yrs. }\end{array}$ & $\begin{array}{c}\text { HR } 3.6 \\
(95 \% \text { CI } 1.4-9.9) \\
p<0.01\end{array}$ & N/A & $\begin{array}{l}\text { Results not } \\
\text { adjusted for } \\
\text { covariates }\end{array}$ & 15 \\
\hline $\begin{array}{c}\text { Gau et al. } \\
2010\end{array}$ & $\begin{array}{l}\text { Cross- } \\
\text { sectional } \\
\text { study }\end{array}$ & $\begin{array}{c}\text { Psychiatrically } \\
\text { referred } \\
\text { (ADHD) } \\
\text { Schools } \\
\text { attended by } \\
\text { participants } \\
\text { w/ ADHD } \\
\text { (controls) } \\
\text { Ages } 11-17 \text { y. } \\
86 \% \text { male; } \\
14 \% \text { female }\end{array}$ & $\begin{array}{l}- \text { Total } \mathrm{N}=481 \\
\circ \text { ADHD } \\
\mathrm{N}=296 \\
\circ \text { Controls } \mathrm{N}= \\
185\end{array}$ & $\begin{array}{l}\frac{\text { Outcomes: }}{\bullet \text { ED-C }} \\
\text { Assessment: } \\
\text { - Chinese KSADS-E }\end{array}$ & $\begin{array}{c}1.6 \% \text { of youth } \\
\text { with persistent } \\
\text { ADHD } \\
\text { compared to } 0 \% \\
\text { of control youth } \\
\text { had ED } \\
\text { p }=0.124\end{array}$ & N/A & $\begin{array}{l}\text { Results not } \\
\text { adjusted for } \\
\text { covariates }\end{array}$ & 17 \\
\hline $\begin{array}{l}\text { Lewinsohn } \\
\text { et al. } 2000\end{array}$ & $\begin{array}{c}\text { Prospective } \\
\text { cohort }\end{array}$ & $\begin{array}{c}\text { Community } \\
\text { sample of } \\
\text { adolescents } \\
\text { girls } \\
\text { Ages } 19-23 \mathrm{y} . \\
100 \% \text { female }\end{array}$ & $\begin{array}{l}- \text { Total } \mathrm{N}=810 \\
\circ \text { ADHD } \\
\mathrm{N}=12 \\
\circ \text { Controls } \mathrm{N}= \\
798\end{array}$ & $\begin{array}{l}\text { Outcomes: } \\
\text { - AN } \\
\text { - BN } \\
\text { - Partial-syndromes } \\
\text { for AN and BN also } \\
\text { examined } \\
\text { Assessment: } \\
\text { - KSADS }\end{array}$ & $\begin{array}{l}\text { 1/23(4.3\%) w/ } \\
\text { partial-syndrome } \\
\text { ED had ADHD } \\
0 / 19(0 \%) \text { with } \\
\text { full-syndrome } \\
\text { ED had ADHD } \\
\text { Finding is NS for } \\
\text { anassociation. }\end{array}$ & N/A & $\begin{array}{l}\text { Results not } \\
\text { adjusted for } \\
\text { covariates }\end{array}$ & 16 \\
\hline $\begin{array}{c}\text { Mikami et } \\
\text { al. } 2008\end{array}$ & $\begin{array}{l}\text { Prospective } \\
\text { cohort }\end{array}$ & $\begin{array}{l}\text { Participants } \\
\text { in summer } \\
\text { research camps } \\
\text { Ages } 11-18 \mathrm{y} \text {. } \\
100 \% \text { female }\end{array}$ & $\begin{array}{l}- \text { Total } \mathrm{N}=209 \\
\circ \text { ADHD } \\
\mathrm{N}=127 \\
\circ \text { Controls } \mathrm{N}= \\
82\end{array}$ & $\begin{array}{l}\text { Outcomes: } \\
\bullet \text { BN symptoms } \\
\text { Assessment: } \\
\text { - DISC-IV } \\
\text { - Eating Disorders } \\
\text { Inventory-II (EDS-II) } \\
\text { - Eating Attitudes } \\
\text { Test (EAT) } \\
\text { - Body Image Survey }\end{array}$ & $\begin{array}{l}\text { No youth met } \\
\text { full } \\
\text { criteria for BN }\end{array}$ & $\begin{array}{l}\text { Childhood } \\
\text { ADHD } \\
\text { diagnosis } \\
\text { predicted } \\
\text { eating } \\
\text { pathology } \\
{[F(4,372)} \\
=2.78] \mathrm{p}< \\
0.05\end{array}$ & $\begin{array}{l}\text { Age, BMI, IQ, } \\
\text { baseline } \\
\text { satisfaction w/ } \\
\text { physical } \\
\text { appearance, } \\
\text { baseline } \\
\text { disruptive and } \\
\text { internalizing } \\
\text { comorbidities, } \\
\text { early puberty, } \\
\text { and stimulant } \\
\text { medication use }\end{array}$ & 12 \\
\hline $\begin{array}{c}\text { Mikami et } \\
\text { al. } 2010\end{array}$ & $\begin{array}{c}\text { Cross-sectio } \\
\text { nal study }\end{array}$ & $\begin{array}{l}\text { Participants in } \\
\text { MTA study } \\
\text { Ages } 15-18 \text { y. } \\
79 \% \text { male; } \\
21 \% \text { female }\end{array}$ & $\begin{array}{l}- \text { Total } \mathrm{N}=696 \\
\circ \mathrm{ADHD} \\
\mathrm{N}=432 \\
\circ \text { Controls } \mathrm{N}= \\
264\end{array}$ & $\begin{array}{l}\text { Outcomes: } \\
\text { • BN symptoms } \\
\text { Assessment: } \\
\text { - DISC-IV } \\
\text { • Eating Disorders } \\
\text { Inventory-II (EDS-II) }\end{array}$ & $\begin{array}{l}\text { No youth met } \\
\text { full } \\
\text { criteria for BN }\end{array}$ & $\begin{array}{c}\text { Youth with } \\
\text { ADHD } \\
\text { displayed } \\
\text { more BN } \\
\text { symptoms } \\
\text { than } \\
\text { controls } \\
{[F(10,448)} \\
=3.38] \mathrm{p}< \\
0.001\end{array}$ & $\begin{array}{c}\text { BMI, age, } \\
\text { pubertal } \\
\text { development, } \\
\text { parent-reported } \\
\text { BN symptoms, } \\
\text { family income, } \\
\text { ethnicity }\end{array}$ & 13 \\
\hline
\end{tabular}




\begin{tabular}{|c|c|c|c|c|c|c|c|c|}
\hline $\begin{array}{l}\text { Neumark- } \\
\text { Sztainer } \text { et } \\
\text { al. } 1995\end{array}$ & $\begin{array}{c}\text { Cross-sectio } \\
\text { nal study }\end{array}$ & $\begin{array}{l}\text { Population- } \\
\text { based data } \\
\text { Ages } 12-20 \text { y. } \\
47 \% \text { male; } \\
53 \% \text { female }\end{array}$ & $\begin{array}{l}- \text { Total } \mathrm{N}=3530 \\
\circ \mathrm{ADHD} \mathrm{N}= \\
689 \\
\circ \text { Other chronic } \\
\text { conditions } \mathrm{N}= \\
1460 \\
\circ \text { Controls } \mathrm{N}= \\
1381\end{array}$ & $\begin{array}{l}\text { Outcomes: } \\
\text { • Individual } \\
\text { behaviors related body } \\
\text { dissatisfaction and } \\
\text { unhealthy dieting } \\
\text { practices } \\
\text { Assessment: } \\
\text { - Youth answered } \\
\text { questions about their } \\
\text { concerns and } \\
\text { satisfaction with } \\
\text { development, body } \\
\text { image, eating } \\
\text { behaviors and weight } \\
\text { loss practices }\end{array}$ & N/A & $\begin{array}{l}\text { All participants } \\
\text { with ADHD } \\
\text { were more } \\
\text { likely to binge, } \\
\text { diet, and vomit } \\
\text { than } \\
\text { control } \\
\text { participants. }\end{array}$ & $\begin{array}{l}\mathrm{BMI}, \text { age, } \\
\mathrm{SES} \text {, and } \\
\text { race }\end{array}$ & 17 \\
\hline $\begin{array}{l}\text { Yates et al. } \\
\quad 2009\end{array}$ & $\begin{array}{l}\text { Cross-sectio } \\
\text { nal/ } \\
\text { case-control } \\
\text { study }\end{array}$ & $\begin{array}{c}\text { Inpatients } \\
\text { hospitalized for } \\
\text { eating } \\
\text { disorders } \\
\text { Age range not } \\
\text { reported; } 65 \% \\
\text { were }<18 \text { y. } \\
(\mathrm{N}=122) \\
100 \% \\
\text { female }\end{array}$ & $\begin{array}{l}- \text { Total } \mathrm{N}=189 \\
\circ \mathrm{ADHD} \mathrm{N}= \\
10 \\
\circ \text { Non-ADHD } \\
\mathrm{N}=179\end{array}$ & $\begin{array}{l}\text { Outcomes: } \\
\bullet \text { AN } \\
\bullet \text { BN } \\
\text { Assessment: } \\
\text { - Structured } \\
\text { Interview for Anorexia } \\
\text { \& Bulimia Nervosa } \\
\text { (BIAB) }\end{array}$ & $\begin{array}{c}5.3 \%(95 \% \mathrm{CI}= \\
2.6 \%-9.5 \%) \\
\text { met criteria for } \\
\text { childhood onset } \\
\text { ADHD. } \\
\text { Finding is NS for } \\
\text { an association. }\end{array}$ & N/A & $\begin{array}{l}\text { Results not } \\
\text { adjusted for } \\
\text { covariates }\end{array}$ & 14 \\
\hline $\begin{array}{l}\text { Yoshimasu } \\
\text { et al. } 2012\end{array}$ & $\begin{array}{l}\text { Population- } \\
\text { based } \\
\text { retrospective } \\
\text { cohort }\end{array}$ & $\begin{array}{c}\text { Population- } \\
\text { based } \\
\text { sample } \\
\text { Ages } 6 \text { - } 17 \text { y. } \\
51 \% \text { male; } \\
49 \% \text { female }\end{array}$ & $\begin{array}{l}\text { - Total } \mathrm{N}=5718 \\
\circ \mathrm{ADHD} \mathrm{N}= \\
343 \\
\circ \text { Controls } \mathrm{N}= \\
712\end{array}$ & $\begin{array}{l}\frac{\text { Outcomes: }}{\bullet \text { ED-C }} \\
\text { Assessment: } \\
\text { • Diagnostic } \\
\text { information abstracted } \\
\text { from school records, } \\
\text { meeting DSM-IV } \\
\text { criteria }\end{array}$ & $\begin{array}{c}\text { HR } 5.6(95 \% \mathrm{CI} \\
1.14-28.21) \\
\mathrm{p}=0.03\end{array}$ & N/A & $\begin{array}{l}\text { Adjusted } \\
\text { for sex, } \\
\text { mother's } \\
\text { age and } \\
\text { educational } \\
\text { level at birth }\end{array}$ & 18 \\
\hline
\end{tabular}

${ }^{\mathrm{a}} \mathrm{AN}$ : Anorexia Nervosa; BN: Bulimia Nervosa; ED-C: Eating Disorders combined; ${ }^{\mathrm{b}}$ /A: Not Assessed.

The remainder of studies did not find an association between ADHD and ED. Two studies by Mikami and colleagues $[19,20]$ examined the association between ADHD and BN in samples of youth attending research camps or enrolled in the Multi-Modal Treatment Study of Children with ADHD (MTA) study. No youth met full diagnostic criteria for $\mathrm{BN}$ in either of the studies, but did show symptoms of EP, the details of which are described below. Yates et al. [23] assessed the prevalence of ADHD among inpatients with eating disorders. Of 189 cases examined, only $10(5.3 \%)$ met criteria of childhood-onset of ADHD. This prevalence of ADHD is similar to what is found in the general population, and thus did not support an association between ADHD and ED.

\subsection{ADHD and Eating Pathology/Eating Disorder Symptoms}

Three studies $[19,20,22]$ examined the association between ADHD and the presence of eating pathologies (EPs) or symptoms of eating disorders in adolescents. Table 2 shows results for symptoms specifically related to EP that were reported by two or more of these studies.
Overall, the results suggest that youth with ADHD were more likely to have higher rates of $\mathrm{EP}$, a desire to lose weight or drive for thinness, higher parent-reported BN symptom counts, and higher rates of body dissatisfaction.

An early study by Neumark-Sztainer et al. [22] used data from the Minnesota Adolescent Health Survey to examine whether youth with chronic health conditions, including youth with ADHD, had unhealthy weight loss practices and evidence of body dissatisfaction. The authors found that compared to youth without ADHD of the same sex, those with ADHD were more likely to engage in pathological eating behaviors and dieting practices, and to report dissatisfaction with their weight.

As noted above, Mikami and colleagues [19,20] assessed BN-related behaviors and symptoms among youth with and without ADHD. Although no youth met full diagnostic criteria for $\mathrm{BN}$ in either study, those with ADHD were more likely to have pathological eating behaviors. In their 2008 study, [20] a 5-year prospective follow-up of girls with ADHD and typically developing peers who attended summer research camps, the authors found that adolescents with ADHD were more likely to 
Table 2. Association between ADHD and EP and ED behaviors/symptoms.

\begin{tabular}{|c|c|c|c|c|}
\hline Study & Eating pathology & $\begin{array}{l}\text { Desire to lose weight/drive } \\
\text { for thinness }\end{array}$ & $\begin{array}{c}\text { Bulimia nervosa symptom } \\
\text { count (parent reported) }\end{array}$ & Body dissatisfaction \\
\hline $\begin{array}{c}\text { Mikami et al., } 2008 \\
\text { (Effect sizes; Cohen's } d \text { ) }\end{array}$ & $0.64^{* *}$ & $0.63^{* *}$ & $0.46^{* *}$ & -- \\
\hline $\begin{array}{l}\text { Mikami et al., } 2010 \\
\text { (Effect sizes; Cohen's } d \text { ) }\end{array}$ & -- & $0.24^{* * *}$ & $0.36^{*}$ & $0.21^{*}$ \\
\hline $\begin{array}{l}\text { Neumark-Sztainer et al., } 1995 \\
\text { (Odds Ratios (95\% CIs)) }\end{array}$ & $\begin{array}{c}\text { Binge eating } \\
\text { Girls } 1.70(1.25-2.3) \\
\text { Boys } 1.94(1.27-2.97) \\
\text { Vomiting } \\
\text { Girls } 2.38(1.57-3.61) \\
\text { Boys } 3.84(2.08-7.06) \\
\text { Laxative use } \\
\text { Girls 3.74 (1.68 - 8.32) } \\
\text { Boys-N/A }\end{array}$ & $\begin{array}{c}\text { Dieting } \\
\text { Girls } 1.93(1.43-2.69) \\
\text { Boys 2.61 }(1.22-5.62)\end{array}$ & -- & $\begin{array}{l}\text { Girls } 2.10(1.56-2.84) \\
\text { Boys } 1.45(1.02-2.07)\end{array}$ \\
\hline
\end{tabular}

${ }^{*} \mathrm{p}<0.05 ;{ }^{* *} \mathrm{p}<0.01 ;{ }^{* * *} \mathrm{p}=0.00$.

have $\mathrm{BN}$ symptoms and body image dissatisfaction than non-ADHD adolescents, after adjusting for a number of covariates. Specifically, adolescents with the combined sub-type of ADHD were more likely than those with the inattentive subtype to have EP. The authors conducted regressions that reversed the order of predictors of parent-child or peer relationship problems and found that in all cases ADHD was a significant predictor of EP. They also found that impulsivity, rather than inattention or hyperactivity, was a significant predictor for EP. Likewise, in their 2010 study, Mikami et al. [19] found that youth with ADHD were more likely than their non-ADHD peers have more $\mathrm{BN}$ symptoms and to score outside of the normative range on measures for drive for thinness, bulimia, and body dissatisfaction. As in their 2008 study, they found that impulsivity was a significant predictor for BN symptoms. The authors also examined the effect of stimulant medication treatment on BN symptoms, and found that the proportion of time on medication was not associated with BN symptomatology.

\section{DISCUSSION}

This systematic review examined the association between ADHD and ED and/or EP in adolescents. Of the eight studies included in this review, two studies [17,24] documented an association between ADHD and ED, and three studies found associations between ADHD and EP $[19,20,22]$. Of the three studies that failed to find an association, two had very small samples of ADHD youth (12 and 10 youth respectively) [21,23]. The third study [18], conducted in China, also failed to find an association but the sample was composed primarily of boys ( $86 \%$ of the sample) and the average age was under 13 yrs., which may have contributed to the null findings, given that ED arises in adolescence and is more com- monly found in girls. Taken together, the five studies documenting and association between ADHD and ED or EP suggest that youth with ADHD may indeed be at higher risk for pathological eating than their typically developing counterparts. Specifically, these findings suggest that youth with ADHD have a higher likelihood than non-ADHD peers to have BN-related symptoms, dissatisfaction with their bodies, and to engage in more dieting behaviors. The results also suggest that ADHD youth with comorbid behavioral health disorders or who experience punitive parenting are at higher risk.

These findings are in keeping with a growing literature that has documented an association between ADHD and ED among adults, [25-29] and may not be surprising given that youth with ADHD are at increased risk for a host of behavioral health and substance abuse disorders. Two prior literature reviews on ADHD and ED by Cortese [30] and Nazar [31] published in 2007 and 2008 respectively, provided overviews of studies in both children and adults. Nazar et al. [31] concluded that although the literature appeared to support a relationship between ADHD and ED, the small number of available studies, many of which had small sample sizes and employed varied methodologies, limited the generalization of findings. Cortese and colleagues' review only included cross-sectional studies which limited the ability to draw conclusions about the direction of the relationship between ADHD and ED. They proposed several hypotheses about this relationship that supports the need for future research [30]. The current review adds to these prior reviews by including newer studies and focusing on adolescents. The current review also applied stricter inclusion criteria, including studies that had sufficient cases to document the prevalence of ED in ADHD (or ADHD in ED). Nonetheless, the literature on pathological eating in ADHD is in its infancy, and as such, suffers from several methodological 
limitations that warrant additional investigation.

Among the studies that documented a positive association between ADHD and ED or EP, the method of classification of eating pathology varied substantially, making it difficult to make true comparisons across samples. Studies used DSM-IV criteria, symptom counts, eating disorders questionnaires, or single questions about eating behaviors. The studies using DSM criteria for ED provided a uniform manner of assessing this outcome; however, other studies used various measures of eating pathology such as the Eating Disorders Inventory, Eating Attitudes Test, Body Image Survey, or self-report of individual behaviors related to eating, dieting, and body dissatisfaction. This made making parallel comparisons of individual eating pathologies across studies difficult. Several studies used parent report or self-report, depending on the age of the participant and the setting. Parent report may have resulted in an under-reporting of eating pathologies, since this is often a behavior that is concealed from others by the patient.

Many of the included studies used cross-sectional designs which prevent conclusions about the direction of the associations between ADHD and ED/EP to be drawn. It is plausible, for example, that eating pathologies could render an individual to appear as if $\mathrm{s} / \mathrm{he}$ has ADHD. Cortese [25] offered a potential hypothesis that EP may contribute to the appearance of ADHD symptoms, in that persons with bulimic or abnormal eating behaviors may interrupt their activities in an impulsive manner in the pursuit of food. In addition, overeating itself may give rise to ADHD-related symptoms. Some limited evidence suggests such an association; for example, short-term lab-based over-feeding studies in non-obese humans have been shown to lead to brain changes including an increase in the activation of the default mode network (DMN) [32]. ADHD is characterized by DMN over-activation and difficulty in suppressing this network during effortful tasks [33,34]. As noted earlier, Yates et al. [23] failed to document an association between ADHD and eating disordered inpatients, although many patients reported current ADHD symptoms, suggesting the possibility that eating disorders may induce ADHD-like symptoms. Likewise, in a study of obese adolescent inpatients, Cortese and colleagues [35] found that ADHD symptoms were associated with symptoms of BN. However, the prospective studies included in this review do lend evidence to suggest that ADHD may be a risk factor for ED in youth, given the elevated hazard ratios reported by both Biederman [17] and Yoshimasu, [24] and the findings from Mikami's study [20] which suggest that ADHD youth were more likely to develop ED or EP over time than youth without ADHD.

While the findings reviewed here suggest that youth with ADHD demonstrate a higher propensity for EP, very few of the studies adjusted for comorbid behavioral health conditions that are common in ADHD. An important question to be answered is whether ADHD itself is responsible for this association or whether it is the comorbid psychopathologies that are common in ADHD that render these youth at higher risk, such as depression and anxiety. Two of the included studies performed analyses that begin to shed light on this question. Biederman [17] conducted a stratified analysis that examined comorbidities among ADHD youth with and without ED, and found that those with co-occurring depression, anxiety, and conduct disorders were more likely to have an ED. Mikami et al. [20] found that the association between EP and ADHD remained after adjusting for a variety of covariates, including internalizing and externalizing conditions. They also reported that punitive parenting practices predicted pathological eating behaviors among girls with ADHD. The authors also found that impulsivity predicted EP, lending evidence that suggests that the core features of ADHD may be contributory. In sum, the results suggest that ADHD is a risk factor for EP and that youth with ADHD who have comorbid psychiatric /behavioral conditions or conflicted parental relationships are at risk.

The role that stimulant medication plays in the association between ADHD and ED/EP merits consideration. If sizeable proportions of youth in the included studies were medicated, this could result in an under-estimation of ED in this population, if the medications used to treat ADHD (i.e., stimulant medications) quell ED symptoms. With the exception of Mikami's study, [19] none of the included studies included information on the medication status of the participants. Although Mikami's findings suggested that medication history was not associated with $\mathrm{BN}$, further investigation on this issue is warranted. As Mikami and colleagues point out, prior research from the MTA study failed to show that medication reduces ADHD and disruptive behavioral symptoms long-term. They also suggested that the null findings could be the result of differential treatment processes that cancel each other out; some youth taking medication may improve by virtue of being treated, while others who are not improving continue on medication for that very reason. In contrast, however, several case reports have suggested that patients with co-morbid eating disorders and ADHD experienced remission of their ED when treated with stimulants [36-39]. The role that medication plays in the both the development and treatment of eating pathology in persons with ADHD will be an important focus for future research.

While eating disorders are more common in females, ADHD is predominantly found in males, with estimated ratios between $2: 1$ and 9:1 of males to females, depending on the subtype of ADHD and source population [40]. 
As noted, half of the studies in this review included samples composed entirely of females [17,20,21,23]. Only Mikami's 2010 study, [19] which included both boys and girls with ADHD, looked at sex-related differences in ADHD and EP. They found that girls were more likely to display BN-related symptoms than boys, and there was no interaction between sex and ADHD diagnosis. Nevertheless, boys with ADHD were more likely to display symptoms related to eating pathology compared to boys without ADHD. Likewise, Neumark-Sztainer [22] found that boys with ADHD were more likely than their nonADHD counterparts to have behaviors and symptoms consistent with EP. These findings suggest that both boys and girls with ADHD may be at increased risk for eating pathology than their non-ADHD peers, and girls with ADHD remain at the highest risk. Given the limited number of studies that included both boys and girls, more research is needed to clarify these relationships and to discern further those factors that may predispose boys and girls with ADHD to develop EP and ED.

In sum, there is mounting evidence of an association between $\mathrm{ADHD}$ and ED; however, larger prospective studies are warranted. Furthermore, none of the studies reviewed here were designed specifically to explore the association between ADHD and ED, but rather took advantage of available data collected from larger studies to address this question. Prospective studies that are designed to explore this association by using robust measures of ED and EP and have the statistical power to adjust for medication effects and the role that co-occurring behavioral health conditions are needed. This line of research has clinical implications for those that work with youth with ADHD. Inquiries about the presence of disordered eating should be included in assessments of patients presenting or being followed for ADHD. If future research further confirms this association and treatment with stimulant medications appears to address ED symptoms, clinicians in the ED field may need to screen for ADHD routinely and consider initiating medical management for ADHD in addition to specific treatments for ED. More research is needed to elucidate the nature of the relationship between ADHD and ED and to evaluate the implications of treating patients with this comorbidity.

\section{REFERENCES}

[1] Ferguson, J.H. (2000) National institutes of health consensus development conference statement: Diagnosis and treatment of attention-deficit/hyperactivity disorder (ADHD). Journal of the American Academy of Child \& Adolescent Psychiatry, 39, 182-193.

http://dx.doi.org/10.1097/00004583-200002000-00018

[2] American Psychiatric Association (1994) Statistical man- ual of mental disorders. American Psychiatric Association, Washington DC.

[3] Swanson, S.A., Crow, S.J., Le Grange, D., Swendsen, J. and Merikangas, K.R. (2011) Prevalence and correlates of eating disorders in adolescents: Results from the national comorbidity survey replication adolescent supplement. Arch Gen Psychiatry, 68, 714.

http://dx.doi.org/10.1001/archgenpsychiatry.2011.22

[4] Pritts, S.D. and Susman, J. (2003) Diagnosis of eating disorders in primary care. American Family Physician, 67, 297-304.

[5] Biederman, J., Monuteaux, M.C., Mick, E., et al. (2006) Psychopathology in females with attention-deficit/hyperactivity disorder: A controlled, five-year prospective study. Biological Psychiatry, 60, 1098-1105.

http://dx.doi.org/10.1016/j.biopsych.2006.02.031

[6] Spencer, T.J., Biederman, J. and Mick, E. (2007) Attention-deficit/hyperactivity disorder: Diagnosis, lifespan, comorbidities, and neurobiology. Journal of Pediatric Psychology, 32, 631-642.

http://dx.doi.org/10.1093/jpepsy/jsm005

[7] Fischer, M., Barkley, R.A., Smallish, L. and Fletcher, K. (2002) Young adult follow-up of hyperactive children: Self-reported psychiatric disorders, comorbidity, and the role of childhood conduct problems and teen CD. Journal of Abnormal Child Psychology, 30, 463-475. http://dx.doi.org/10.1023/A:1019864813776

[8] Mannuzza, S., Klein, R.G., Bessler, A. and Malloy, P. (1993) Adult outcome of hyperactive boys: Educational achievement, occupational rank, and psychiatric status. Archives of General Psychiatry, 50, 565-576.

http://dx.doi.org/10.1001/archpsyc.1993.0182019006700 7

[9] Barkley, R.A. (1997) Behavioral inhibition, sustained attention, and executive functions: Constructing a unifying theory of ADHD. Psychological Bulletin, 121, 65. http://dx.doi.org/10.1037/0033-2909.121.1.65

[10] Davis, C., Levitan, R.D., Smith, M., Tweed, S. and Curtis, C. (2006) Associations among overeating, overweight, and attention deficit/hyperactivity disorder: A structural equation modelling approach. Eating Behavior, 7, 266-274. http://dx.doi.org/10.1016/j.eatbeh.2005.09.006

[11] Ivan, I., Azarbad, L., Corsica, J. and Hood, M. (2009) Does binge eating mediate the relationship between ADHD characteristics and obesity severity. Obesity, 17, S286.

[12] Guerrieri, R., Nederkoorn, C. and Jansen, A. (2007) The interaction between impulsivity and a varied food environment: Its influence on food intake and overweight. International Journal of Obesity, 32, 708-714. http://dx.doi.org/10.1038/sj.ijo.0803770

[13] Nederkoorn, C., Guerrieri, R., Havermans, R., Roefs, A. and Jansen, A. (2009) The interactive effect of hunger and impulsivity on food intake and purchase in a virtual supermarket. International Journal of Obesity, 33, 905912. http://dx.doi.org/10.1038/ijo.2009.98

[14] Dawe, S. and Loxton, N.J. (2004) The role of impulsivity in the development of substance use and eating disorders. Neuroscience \& Biobehavioral Reviews, 28, 343-351. 
http://dx.doi.org/10.1016/j.neubiorev.2004.03.007

[15] Downs, S.H. and Black, N. (1998) The feasibility of creating a checklist for the assessment of the methodological quality both of randomised and non-randomised studies of health care interventions. Journal of Epidemiological Community Health, 52, 377-384.

http://dx.doi.org/10.1136/jech.52.6.377

[16] Livingston, J.D., Milne, T., Fang, M.L. and Amari, E. (2012) The effectiveness of interventions for reducing stigma related to substance use disorders: A systematic review. Addiction, 107, 39-50.

http://dx.doi.org/10.1111/j.1360-0443.2011.03601.x

[17] Biederman, J., Ball, S.W., Monuteaux, M.C., Surman, C.B., Johnson, J.L. and Zeitlin, S. (2007) Are girls with ADHD at risk for eating disorders? Results from a controlled, five-year prospective study. Journal of Developmental and Behavioral Pediatrics, 28, 302-307. http://dx.doi.org/10.1097/DBP.0b013e3180327917

[18] Gau, S.S., Ni, H.C., Shang, C.Y., et al. (2010) Psychiatric comorbidity among children and adolescents with and without persistent attention-deficit hyperactivity disorder. Australian \& New Zealand Journal of Psychiatry, 44, 135143. http://dx.doi.org/10.3109/00048670903282733

[19] Mikami, A.Y., Hinshaw, S.P., Arnold, L.E., et al. (2010) Bulimia nervosa symptoms in the multimodal treatment study of children with ADHD. International Journal of Eating Disorders, 43, 248-259.

[20] Mikami, A.Y., Hinshaw, S.P., Patterson, K.A. and Lee, J.C. (2008) Eating pathology among adolescent girls with attention-deficit/hyperactivity disorder. Journal of Abnormal Psychology, 117, 225-235. http://dx.doi.org/10.1037/0021-843X.117.1.225

[21] Lewinsohn, P.M., Striegel-Moore, R.H. and Seeley, J.R. (2000) Epidemiology and natural course of eating disorders in young women from adolescence to young adulthood. Journal of the American Academy of Child \& Adolescent Psychiatry, 39, 1284-1292. http://dx.doi.org/10.1097/00004583-200010000-00016

[22] Neumark-Sztainer, D., Story, M., Resnick, M.D., Garwick, A. and Blum, R.W. (1995) Body dissatisfaction and unhealthy weight-control practices among adolescents with and without chronic illness: A population-based study. Archives of Pediatrics \& Adolescent Medicine, 149, 13301335. http://dx.doi.org/10.1001/archpedi.1995.02170250036005

[23] Yates, W.R., Lund, B.C., Johnson, C., Mitchell, J. and McKee, P. (2009) Attention-deficit hyperactivity symptoms and disorder in eating disorder inpatients. International Journal of Eating Disorders, 42, 375-378. http://dx.doi.org/10.1002/eat.20627

[24] Yoshimasu, K., Barbaresi, W.J., Colligan, R.C., et al. (2012) Childhood ADHD is strongly associated with a broad range of psychiatric disorders during adolescence: A population-based birth cohort study. Journal of Child Psychology and Psychiatry, 53, 1036-1043. http://dx.doi.org/10.1111/j.1469-7610.2012.02567.x

[25] Cortese, S., Bernardina, B.D. and Mouren, M.C. (2007) Attention-Deficit/hyperactivity disorder (ADHD) and binge eating. Nutrition Reviews, 65, 404-411. http://dx.doi.org/10.1111/j.1753-4887.2007.tb00318.x

[26] Mattos, P., Saboya, E., Ayrão, V., Segenreich, D., Duchesne, M. and Coutinho, G. (2004) Comorbid eating disorders in a brazilian attention-deficit/hyperactivity disorder adult clinical sample. Revista Brasileira de Psiquiatria, 26, 248-250.

[27] Wentz, E., Lacey, J.H., Waller, G., Rastam, M., Turk, J. and Gillberg, C. (2005) Childhood onset neuropsychiatric disorders in adult eating disorder patients. A pilot study. European Child \& Adolescent Psychiatry, 14, 431-437. http://dx.doi.org/10.1007/s00787-005-0494-3

[28] Surman, C.B., Randall, E.T. and Biederman (2006) Association between attention-deficit/hyperactivity disorder and bulimia nervosa: Analysis of 4 case-control studies. Journal of Clinical Psychiatry, 67, 351-354. http://dx.doi.org/10.4088/JCP.v67n0303

[29] Nazar, B.P., Pinna, C.M., Suwwan, R., et al. (2012) ADHD rate in obese women with binge eating and bulimic behaviors from a weight-loss clinic. Journal of Attention Disorders, 28, Epub ahead of print.

[30] Cortese, S., Isnard, P., Bernardina, B.D. and Mouren, M. (2007) Attention-deficit/hyperactivity disorder, binge eating, and obesity. Journal of Clinical Psychiatry, 68, 976. http://dx.doi.org/10.4088/JCP.v68n0624h

[31] Nazar, B.P., Pinna, C.M., Coutinho, G., et al. (2008) Review of literature of attention-deficit/hyperactivity disorder with comorbid eating disorders. Revista Brasileira de Psiquiatria, 30, 384-389. http://dx.doi.org/10.1590/S1516-44462008000400014

[32] Tregellas, J.R., Wylie, K.P., Rojas, D.C., et al. (2012) Altered default network activity in obesity. Obesity, 19, 2316-2321. http://dx.doi.org/10.1038/oby.2011.119

[33] Castellanos, F.X., Margulies, D.S., Kelly, A.M.C., et al. (2008) Cingulate-precuneus interactions: A new locus of dysfunction in adult attention-deficit/hyperactivity disorder. Biological Psychiatry, 63, 332. http://dx.doi.org/10.1016/j.biopsych.2007.06.025

[34] Fassbender, C., Zhang, H., Buzy, W.M., et al. (2009) A lack of default network suppression is linked to increased distractibility in ADHD. Brain Research, 1273, 114-128. http://dx.doi.org/10.1016/j.brainres.2009.02.070

[35] Cortese, S., Isnard, P., Frelut, M.L., et al. (2007) Association between symptoms of attention-deficit/hyperactivity disorder and bulimic behaviors in a clinical sample of severely obese adolescents. International Journal of Obesity, 31, 340-346. http://dx.doi.org/10.1038/sj.ijo.0803400

[36] Dukarm, C.P. (2005) Bulimia nervosa and attention deficit hyperactivity disorder: A possible role for stimulant medication. Journal of Women's Health, 14, 345-350. http://dx.doi.org/10.1089/jwh.2005.14.345

[37] Drimmer, E.J. (2003) Stimulant treatment of bulimia nervosa with and without attention-deficit disorder: Three case reports. Nutrition, 19, 76-77. http://dx.doi.org/10.1016/S0899-9007(02)01045-6

[38] Schweickert, L.A., Strober, M. and Moskowitz, A. (1997) Efficacy of methylphenidate in bulimia nervosa comorbid with attention-deficit hyperactivity disorder: A case report. International Journal of Eating Disorders, 21, 299- 
301.

http://dx.doi.org/10.1002/(SICI)1098-108X(199704)21:3 $\leq 299::$ AID-EAT11>3.0.CO;2-W

[39] Lena, S., Chidambaram, U., Panarella, C. and Sambasivan, K. (2001) Cognitive factors in anorexia nervosa: A case history. International Journal of Eating Disorders, 30, 354-358. http://dx.doi.org/10.1002/eat.1097
[40] Rucklidge, J.J. (2010) Gender differences in attention-deficit/hyperactivity disorder. Psychiatric Clinics of North America, 33, 357.

http://dx.doi.org/10.1016/j.psc.2010.01.006 